Prof. C. V. Riley has just published, in the Second Report of the United States Entomological Commission, "Further Facts about the Natural Enemies of Locusts," meaning, of course, by the latter term, the Rocky Mountain pest in particular. His observations entirely concern insect parasites. The most interesting are on the habits of two species of Diptera, allied to Bombylius, the larvæ of which feed on the eggs of "locusts." The plate (xvi.) illustrating the subject is above praise, not only on account of the scientific accuracy shown in the drawings (which are by the author), but also as regards the reproduction of them by the "lithocaustic" process adopted by a Baltimore firm. We have seen other plates of entomological subjects emanating from the same firm, and the impression formed on our mind is that no other process is equally adapted for the purpose. Why cannot some of our own enterprising "lithographers" produce the same result?

THE following are the lecture arrangements after Easter, at the Royal Institution :-P Prof. Dewar, M.A., F.R.S., six lectures on the Non-Metallic Elements, on Tuesdays, A pril 26 to May 31 ; Prof. Tyndall, D.C.L., F.R.S., six lectures on Paramagnetism and Diamagnetism, on Thursdays, April 28 to June 2; Prof. H. Morley, three lectures on Scotland's Part in English Literature, on Saturdays, April 30, May 7, 14; one lecture on Thomas Carlyle, on Tuesday, June 7; Mr. E. C. Turner, Lector at the University of St. Petersburg, five lectures on the Great Modern Writers of Russia, on Saturdays, May 2I, 28, June 4, Thursday, June 9, and Saturảay, June II. The Friday evening meetings will be resumed on April 29, at 8 p.m. Prof J. S. Blackie, F.R.S.E., will give a discourse on "The Language and Literature of the Scottish Highlands," at 9 p.m. Succeeding discourses will probably be given by the Hon, G. C. Brodrick, Mr. Francis Galton, Mr. W. H. Pollock, Prof. H. E. Roscoe, Prof. W. G. Adams, and Prof. Dewar.

THE usual course of Mayfair Lectures will commence, under the auspices of the National Health Society, on Friday, April 22, at 23, Hertford Street, Mayfair. The list of lecturers will this year include the names of Dr. Siemens, F.R.S., Dr. Robert Farquharson, M.P., and Prof. Fleeming Jenkin.

WE are glad to find from an anmouncement in the current number of the Quarterly Fournal of Microscopical Science that Dr. C. T. Hudson, of Manilla Hall, Bristol, is preparing a volume for the Ray Society on the "British Rotifers." Dr. Hudson is known not only for his numerous cantributions to our knowledge of this group, but especially for his discovery and excellent illustrations of one of the most important members of the group (Pedalion). Dr. Hudson will have the advantage of the use of Mr. P. H. Gorse's beautiful drawings of Rotifers, which that observer has placed at his disposal.

A LARGE party of the Members of the Geologists' Association were on Saturday last conducted through the Geological Department of the British Museum (Natural History), South Ken. sington, by Dr. Henry Woodward, F.R.S., \&c., the Keeper of that Department.

Apropos of the meeting of the French Association at Algiers the Revue Scientifique for April 9 devotes most of its space to a series of articles on Algeria, its colonisation, statistics, botany, anthropology, hygiene, and zoclogy.

THE additions to the Zoological Society's Gardens during the past week include a Macaque Monkey (Macacus cynomolgus) from India, presented by Mr. R. J. Short; a Common Paradoxure (Paradoxurus typus), from India, presented by Mr. C. W. C. Fletcher; a Viverrine Cat (Felis vizerrina) from India, pre. sented by Major C. R. Oxley; two Squirrel-like Phalangers (Belideus sciureus) from Australia, presented by Mr. D. W.
Barker; three Paradise Whydah Birds (Vidua paradisea), a Pintailed Whydah Bird (Vidua principalis), a Red-shouldered Weaver Bird (Urobrachya axillaris), a Red-beaked Weaver Bird (Quelea sanguinirostris), a Wiener's Finch (Pytelia wieneri), two Yellow-rumped Seed-Eaters (Crithagra chrysopyga) from Mozambique, presented by Mr. Maurice C. Angel, F.Z.S. ; two Laughing Kingfishers (Dacelo gigantea) from Australia, presented by Mr. Edwaxd Trelawny; an Alexandrine Parrakeet (Palcoornis alexandri) from India, presented by Mr. Henry Day; a Common Gannet (Sula bassana), British, presented by Mr. G. Randall; a Common Marmoset (Hapale jacchus) from South America, deposited; an Indian Chevrotain (Tragulus meminna) from India, six Weeper Capuchins (Cebus capucinus) from Brazil, four Chestnut-eared Finches (Amadina castanotis) from Australia, three Common Crowned Pigeons (Goura coronata) from New Guinea, an American Tantalus (Tantalus loculator) from South America, purchased; two Sclater's Curassows (Crax sclateri o $q)$ from South America, on approval; an Indian Darter (Plotus melanogaster) from India, received in exchange.

\section{GEOGRAPHICAL NOTES}

ThE Royal Medals of the Geographical Society have this week been awarded as follows :-The Founder's Medal to Major Serpa Pinto, "for his remarkable journey across Africa, from Benguela to Natal, during which he explored nearly 500 miles of new country, defined the fluvial systems of the southern slopes of the Benguelan Highlands, and fixed the position of numerous places by a series of astronomical observations; also for the admirable account of his journey, now in course of publication in London, containing numerous original maps, tables of observations, and a large amount of valuable and exact information regarding the African interior ;" and the Patron's Medal to Mr. Benjamin Leigh Smith, for his discoveries on the south coast of Franz-Josef Land during last summer, as well as for his previous expeditions along the north east land of Spitzbergen.

AT the meeting of the Geographical Society on Monday last Mr. R. N. Cust read a paper by Col. Tanner on Kafiristan and the Siah-posh Kafirs of the Hindu Kush. The paper, which was hardly a geographical one in any sense, dealt chiefly with the inhabitants of the Valley of Dara Nur and the Chugan tribe, and to a less extent with the Kafirs, who are called "Siahposh" from their wearing black clothes, and furnished some very interesting information regarding their manners and customs. Some philological notes had also been sent by Col. Tanner, but these will be communicated to the Asiatic society. Some of the more striking passages in Col. Tanner's notes, if we remember rightly, were read at the Swansea meeting of the British Association. As much interest attaches to Kafiristan and the Kafirs, and the results expected from Col. Tanner's expedition were so eagerly looked forward to, it was rather disappointing to be told by $\mathrm{Col}$. Yule that we have even now learned no more than was buried in the record of a Jesuit Missionary's travels some 200 years ago. No doubt had his health not failed at the critical moment, and compelled him to return to India, Col. Tanner would have succeeded in penetrating into Kafiristan itself, and collected valuable geographical information.

THE Society formed at Milan for commercial exploration in Africa is showing increased activity, and has despatched another expedition to Tripoli, under the command of Capt. Camperio, who is ascompanied by Signor Cingia, an ex-cavalry officer. The principal objects of this expedition are the exploration of the Gulf of Bomba, and it will particularly examine the ports of Tobruek and Derna, not far from the Egyptian frontier. Capt. Camperio will afterwards make an attempt to penetrate into the interior of the oasis of Jazabud, in order to open commercial relations with its inhabitants.

WE are glad to learn that there is good hope that Col. Flatters and many of his followers, who were reported to have been massacred by the Touaregs, are still alive, though probably retained as prisoners.

DOCTORS SCHWEINFURTH AND RIEBECK, who have been travelling in Egypt, left Cairo last month to explore the island of Socotra. They do not seem to be aware that quite recently 
Prof. I. B. Balfour visited the island on behalf of our Zoological Society.

THE April number of Petermann's Mittheilungen has a long article, with map, on Mr. A. Forrest's expedition through North-West Australia in 1879; Herr Clemens Denhardt con. tinues his paper on Researches in Equatorial East Africa; Herr F. v. Stein gives details on the new French land fortifications, with map, and there are several interesting letters from Dr. Junker, on his experiences in the Niam-Niam country.

No. 2, for 1880, of the Bulletin of the American Geographical Society contains an unusually interesting paper by Prof. J. B. M'Master, of Princeton College, on the Bad Lands of Wyoming, in which he endeavours to trace out their geological history; Mr. B. R. Curtis describes his journey round the world; and there is a historical article on Arctic Exploration by the Rev. B. F. De Costa.

THE Bulletin of the Antwerp Geographical Society (tome v. fasc. 6) contains a paper of considerable value by the Abbé van den Gheyn, on the present state of research with regard to the primitive cradle of the Aryan race. M. A. Baquet contributes a paper on the fauna and the chace in the countries of South America watered by the Paraguay and the Parana.

\section{CHEMICAL NOTES}

B. HEINDL has recently made investigations into the compounds of calcium chloride with ethyl alcohol, isobutyl alcohol, and amyl alcohol, an $i$ has obtained the following formula:$\mathrm{CaCl}_{2} \cdot 3\left(\mathrm{C}_{2} \mathrm{H}_{6} \mathrm{O}\right) ; \mathrm{CaCl}_{2} \cdot 3\left(\mathrm{C}_{4} \mathrm{H}_{10} \mathrm{O}\right)$; and $\mathrm{CaCl}_{2} \cdot 3\left(\mathrm{C}_{5} \mathrm{H}_{12} \mathrm{O}\right)$.

IN continuation of his investigation of the action of hydrochloric acid on metallic chlorides, alreacly referred to in these notes, M. Ditté describes several new compounds of this acid with mercuric chloride, viz.,

$2 \mathrm{HgCl}_{2} \cdot{ }_{4} \mathrm{HCl} \cdot 7 \mathrm{H}_{2} \mathrm{O}: 3 \mathrm{HgCl}_{2} \cdot{ }_{4} \mathrm{HCl} \cdot 7 \mathrm{H}_{2} \mathrm{O}$ : $2 \mathrm{HgCl}_{2}$. $\mathrm{HCl} .6 \mathrm{H}_{2} \mathrm{O}: 4 \mathrm{HgCl}_{2}, 2 \mathrm{HCl}, 9 \mathrm{H}_{2} \mathrm{O}$ : $3 \mathrm{HgCl} \cdot \mathrm{HCl} \cdot{ }_{5} \mathrm{H}_{2} \mathrm{O}$.

and

MM. Fouque And Levy describe (in Compt. rend.) the artificial preparation of the basaltic minerals peridote and labradorite, by prolonged heating of a homogeneous mixture of the constituents of a basalt rich in olivine.

DR. A. R. LEeDs has recently examined the action of nitrogen tetroxide $-\mathrm{N}_{2} \mathrm{O}_{4}$-on various hydrocarbons (Fourn. of American Chem. Soc.). The results are interesting, and promise to be even rnore so. Benzene, when acted on by $\mathrm{N}_{2} \mathrm{O}_{4}$ yields mononitro-benzene, picric acid and oxalic acid; two other compounds were also obtained, but under conditions which have not been successfully realised a second time. One of these the author calls monoxy-benzene- $-\mathrm{C}_{6} \mathrm{H}_{4} \mathrm{O}$-an isomer or metamer of quinone the other has not been purified. Naphthalene yields mononitronaphthalene, $\alpha$ and $\beta$ dinitro-naphthalene, and two compounds which, so far as they have been examined, appear to be napthodiquinone, $\mathrm{C}_{10} \mathrm{H}_{4} \mathrm{O}_{4}$, and tetroxy-naphthalene, $\mathrm{C}_{10} \mathrm{H}_{8} \mathrm{O}_{4}$. The products of the action of nitrogen tetroxide on cymene are chiefly a nitrocymene (probably also a dinitro derivative) and paratoluic acid.

The American Chem. Soc. Fournal (vol. i. Nos. II and 12) contains an interesting historical sketch of the lines of discovery of ozone, and of peroxide of hydrogen, by Dr. A. R. Leeds; to these papers is added a full list of references to all publica. tions on ozone and hydrogen peroxide; the ozone references occupy thirty-two pages, and the hydrogen peroxide, ten pages.

AN important paper by M. Étard-important both by reason of the results obtained and because of the nature of the problem attacked - on the oxidising action of chromyl dichloride, appears in Annales Chim. et Phys. for February. M. Étard has studied the mechanism, so to speak, of the chemical changes which occur when chromyl dichloride acts as an oxidiser; he finds that in the case of the hydrocarbons containing methyl groups attached to an "aromatic" nucleus the methyl groups are trans. formed into the aldehydic group $(\mathrm{COH})$, and that when the aromatic nuclei are themselves attacked, quinones are produced. The chromyl dichloride forms compounds with the aromatic hydrocarbons, which may be formulated as X . $2 \mathrm{CrO}_{2} \mathrm{Cl}_{2}$ (where $\mathrm{X}=$ hydrocarbon) : these compounds are then decomposed by water, and yield the products already mentioned.
IN the same journal there is a lengthy and interesting paper by $M$. W. Spring on the effects of great pressure on solid bodies. It is shown in this paper-which is chiefly physicalthat the particles of crystalline bodies tend to solder themselves closely together at high pressures, the effect of pressure being analogous to that of fusion; and that amorphous bodies may be divided into two classes, viz. those which behave similarly with crystalline bodies, and those which are not thus affected by high pressures.

THE influence of pressure on chemical changes is also considered, and it is shown that as a general rule a chemical change which results in the production of a system the volume of which is less than the volume of the initial system, may be brought about by subjecting the initial system to great pressure, but that if the change involves an increase of volume, pressure alone does not cause the change to proceed.

M. BRAME describes (in Compt. rend.) experiments on animals with pure hydrocyanic acid, the results of which seem to show that the bodies of animals killed by this acid (pure) do not undergo decomposition even when kept for a month; that the acid remains during that time in the animal tissues, and notably in the stomach, and that the acid is readily obtained by distillation from the tissues of a herbivorous, but much less readily from those of a carnivorous animal.

IN continuing his researches on chemical affinity Herr Ostwald (Fourn. für pract. Chem.) has made the remarkable observation that while the solvent action of polybasic acids on salts is diminished by the presence of the normal salts of the acids employed, the solvent action of monobasic acids is considerably increased by the presence of the normal salts of these acids. In his third paper Herr Ostwald gives a large series of measurements which show that the solvent action of free nitric or hydrochloric acid on calcium or zinc oxalate is increased by addition of potassium, sodium, ammonium, or magnesium nitrate or chloride. The solvent action increases proportionally to the increase in the quantity of normal salt added. Ostwald confesses that he can as yet give no thoroughly satisfactory explanation of this phenomenon; the explanation which appears at present most probable involves the assumption that there is a slight chemical action between the normal salt (potassium nitrate, \&c.) and the salt which is being dissolved by the acid (calcium or zinc oxalate): this small chemical change alters the "stability" of the whole system, and so increases the amount of the primary change, i.e. solution of calcium oxalate, \&c., in a given time.

From thermochemical data $J$. Thomsen regards the generally accepted formula for benzene as incorrect. The number obtained by him for the heat of combustion of benzene $(805,800$ thermal units) agrees fairly well with that calculated $(800,400)$, on the assumption that all the carbon atoms in benzene are "singlylinked." The heat of combustion of the metamer of benzene, viz. dipropargyl, is, according to Berthelot, 853,600 units; Thomsen's caculations, assuming the formula

$$
\mathrm{HC} \equiv \mathrm{C}-\mathrm{CH}_{2}-\mathrm{CH}_{2}-\mathrm{C} \equiv \mathrm{CH}
$$

to be correct, give the number 888,400 . The formula above given for dipropargyl is therefore probably correct.

In the last number of the German Chemical Society's Berichte are published some recent observations on dipropargyl by Henry, the discoverer of this curious compound. He describes, but not yet in any detail, a solid polymer produced by the action of heat on dipropargyl. $\mathrm{He}$ also describes the tetrioaide $\mathrm{C}_{6} \mathrm{H}_{6} \mathrm{I}_{4}$, and the octobromide $\mathrm{C}_{6} \mathrm{H}_{6} \mathrm{Br}_{8}$.

THE arguments in favour of the number 240 being adopted as the atomic weight of uranium have been strengthened by the preparation by C. Zimmermann (Berliner Berichte) of the normal uranate of lithium, $\mathrm{Li}_{2} \mathrm{UO}_{4}$, analogous with the normal chromates, tungstates, and molybdates.

In the Chem. Soc. Fourn. for March Dr. Ramsay continues his investigations on atomic and molecular volumes; he adduces evidence in support of the number 7 as representing the atomic volume of nitrogen; the generally-accepted number is $2 \cdot 3$. He also shows that the molecular volumes of compounds of the benzene, naphthalene, and anthracene series are smaller than those calculated from the best established atomic volumes of the constituent elements, and his numbers suggest that the condensation in these compounds may very probably be proportional to the number of carbon atoms in each molecule, and also to the manner of "linking" of these atoms. 